\title{
Causes and Solutions for the Economic Crisis According to the International Scientific Community*
}

\author{
Causas y soluciones a la crisis financiera según \\ la comunidad científica internacional
}

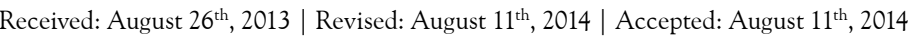

\author{
IZABELA ZYCH ** \\ ROSARIO ORTEGA-RUIZ \\ MARCOS MONJE LÓPEZ \\ VICENTE J. LLORENT \\ Universidad de Córdoba, España
}

doi:10.11144/Javeriana.upsy14-1.csec

Para citar este artículo: Zych, I., Ortega-Ruiz, R. Monje-López, M., \& Llorent, V. J. (2015). Causes and solutions for the economic crisis according to the international scientific community. Universitas Psychologica,14(1), 367-380. http://dx.doi.org/10.11144/ Javeriana.upsy14-1.csec

* Original research article

*** E-mails:izych@uco.es, edlorrur@uco.es, m62molom@uco.es,vjllorent@uco.es

\section{A B S T R A C T}

The current economic crisis started in the USA between 2007 and 2008, and its causes are still being discussed. Although there are many theoretical proposals that analyze the causes and possible solutions to this situation, the number of empirical research is still very scarce. The objective consisted of collecting and analyzing the opinion of the world scientific community on the causes and possible solutions to the crisis. 1770 scientists answered a questionnaire specifically designed for this purpose. Results show that the causes of the economic crisis depended on the management inside and outside the financial institutions. The highest percentage of participants was in agreement with a solution that promotes private initiative but also with governmental help and control.

Keywords

economic crisis; opinion on causes and solutions; international scientific community

\section{RESUMEN}

La actual crisis económica iniciada en los EEUU entre 2007 y 2008, y sus causas todavía se están discutiendo. Aunque hay muchas propuestas teóricas que analizan las causas y posibles soluciones a esta situación, el número de investigaciones empíricas aún es escaso. El objetivo de esta investigación consistió en recoger y analizar la opinión de la comunidad científica mundial sobre las causas y posibles soluciones a la crisis. 1770 científicos respondieron un cuestionario específicamente diseñado para este propósito. Los resultados muestran que las causas de la crisis económica dependieron de la gestión interna y externa de las instituciones financieras. El porcentaje más alto de participantes está de acuerdo con una solución que promueva la iniciativa privada, pero con control y ayuda de los gobiernos.

Palabras clave

crisis económica; opinión sobre causas y soluciones; comunidad científica internacional 
The economic downturn started in the United States between 2007-2008. In the last years, analyses of the crisis focused on finding causes, consequences and also solutions to this situation, although in most cases only the economic-financial point of view was taken into account (Claessens, Dell'Ariccia, Igan, \& Laeven, 2010). For this purpose, international scientific literature started to define the principal characteristics of the crisis based on different economic reports on the subject compared to the previous crises with similar circumstances (Reinhart \& Rogoff, 2009). It seems that the beginning of the crisis could be attributed to the financial fraud (United States. Financial Crisis Inquiry Commission, 2011), an issue of concern to those who recognize it, together with the recession in many different countries, stimulated research on the causes and effects of the crisis.

As already mentioned, it seems that the crisis began in the USA. Nevertheless, the globalization of the financial and economic systems caused a rapid spread of this downturn to other countries. Decreased Gross Domestic Product (GDP) during more than two consecutive trimesters made evident the existence of the crisis and, therefore, governments had to recognize this situation (Dávila \& González, 2009). The decrease could be observed in smaller production of goods and services, smaller consumption of energy, reduction of savings and investment and negative inclination of the commercial balance (García de Fuentes \& Morales, 2013). These characteristics can be clearly observed in the current macroeconomic world panorama (Kirman, 2010).

When the crisis was recognized, research was conducted with the objective of describing its causes. It seems that the existence of the crisis is now broadly recognized; nevertheless, there is no agreement in relation to its origin. Posner (2009) points out the expansionist monetary policy of the Federal Reserve (FR) as the principal cause of the crisis, especially in the 2000's. Another important issue is the lack of financial regulation related to mortgage and credits, impossible to be assumed by the banks (Crotty, 2009). At the same time, after the bankruptcy of Lehman Brothers in September
2008 (Allen \& Carletti, 2010), Espinosa (2013) described three main causes of the crisis: deficient management of the world macroeconomics, inadequate financial regulations, which were related to the US governments (Wallison, 2009), and the rapid growth of the over the counter (OTC) derivatives related to the negotiations of financial instruments such as shares, bonds, row material or mortgage derivatives. These and similar causes put the financial institutions in a spotlight as the most important agents, which promoted policies leading to the crisis, criticism received in many occasions from the principal world leaders (Vasco \& Porporatto, 2011).

On the other hand, research attributes the principal cause of the economic crisis to the central and governmental policies. Some analysts claim that governance of financial institutions was not worst than governance of other institutions (Adams, 2012). Moreover, not all the banks gave the same response to the crisis and some adopted very appropriate measures while managing the crisis Beltratti and Stulz (2012). Therefore, an important part of the origin and development of the economic crisis can be attributed to the governmental policies. These policies contributed to the decrease in the most important services that respond to the basic needs of people, such as health services, science or education (Baker, Bloom, \& Davis, 2013), causing psychological distress with increased prevalence of mental disorders, depression, anxiety and decreased psychological wellbeing (Anagnostopoulos \& Sumaki, 2013; Christodoulou \& Anagnostopoulos, 2013; Gili, Roca, Basu, Mckee \& Stuckler, 2012).

Therefore, analysts seem to be divided into two groups, one that attributes the main cause of the economic crisis to global and local financial institutions (Acharya \& Richardson, 2009; Archarya \& Schnabl, 2010) and the other that gives more importance to governmental policies (Lichtensztejn, 2013). Other studies analyze many different causes, some related to the governments and other linked to institutions, as for example a report released by Rose and Spiegel (2012), which points out the following causes of the current situation: financial system policies and conditions; asset price apprecia- 
tion in real estate and equity markets; international imbalances and foreign reserve adequacy; macroeconomic policies; and institutional and geographic features. There is no agreement on the causes of the crisis and it seems that it is a multicausal phenomenon (Nadal, 2008), related to the policies inside and outside financial institutions (Moreno, 2010).

Different causes of the crisis were described also depending on a geographic zone. In the United States of America, one of the most important causes was related to the construction bubble (Martin, 2011) and the variation of oil prizes (Kilian \& Hicks, 2012). In Europe, there are important differences among the countries, and the southern Europe is much more affected by the crisis in comparison to its northern part (Dolls, Fuest, \& Peichl, 2010). For example, in Spain, it has been emphasized that the deficient management of the real estate and banking sector worsened the effects of the crisis (Carballo, 2011). In Greece, analysts give importance to the deficient macroeconomic management between 2001 and 2009 (Arghyrou $\&$ Tsoukalas, 2011).

On the other hand, in Asia, the emergent economy has been less affected by the crisis if compared to other continents (Aalbers, 2009) and the main cause seems to be attributed to the contagion from other geographic zones. Research in Australia focused on the importance of the world economic imbalance and the existence of an adequate legislation, which could palliate the effects of the crisis (Blundell, Atkinson, \& Lee, 2008). In Africa and Latin America, the causes of the crisis seemed similar to those described in the United States, although the effects of the crisis are not as observable as in other geographic zones, and those areas are experiencing stagnation in the economic growth (IMF, 2009). The causes of the crisis described in those zones are related to high levels of poverty currently exacerbated by inflation in food prices and main raw materials, as well as political corruption of last decade (Mesa-Lago \& Carmel, 2009; Rojas, 2009).

As already described, the impact of the crisis is different in different parts of the world and there is no agreement in relation to its causes. Another important issue is the way in which different gov- ernments are trying to manage the crisis, giving different solutions to the current problems. Countries with the visible impact of the crisis are trying to apply different measures, on one hand, related to cuttings and austerity and, on the other, promoting the economic growth (Bibow, 2013). Among different possible solutions to the crisis, probably the most commonly adopted are related to public spending, control of private institutions, taxation, public employment and private employment. As explained above, the causes of the crisis were related to the governments vs. private financial institutions. Similar situation can be found in case of the solutions which, on one hand, could be focused on public capital control where governments who work and distribute goods and jobs to overcome the crisis and, on the other hand, private capital control where private companies and people are the most important agents in improving this situation.

Taking into account the public spending, one possible solution would consist of increasing taxation, and therefore the governmental income, so that the government would re-distribute the money increasing public spending (i.e. on public health, education, infrastructure, public establishments, etc.) and promoting public employment. On the other hand, another possible solution would be related to the promotion of the private initiative, giving more freedom to the companies, decreasing taxation and cutting public spending. These theoretical extremes would be articulated in a point in between where different combinations of these solutions are being put into practice in different countries (Crotty, 2012).

The financial crisis caused a decrease in the revenues and an increase in the expenditures of governments (Wahrig \& Gancedo Vallina, 2011), which makes the situation unsustainable. At the same time, the taxation question is very difficult to manage as low taxation means less money for the governments to be re-distributed, austerity and cutting public spending, but high taxation means fiscal pressure on individuals and private sector, which therefore has less money to spend or invest. In times of crisis, most of the countries put into practice strategies to control tax evasion and 
fraud (Brondolo, 2009). Countries such as Lithuania, Hungary or Poland reduced personal income taxes and the UK, Czech Republic and Sweden decreased the corporate tax rate with the objective of stimulating the economy (Terazi \& Şenel, 2011; Zai, 2012).

Promoting public vs. private initiative while managing the crisis is also related to the freedom given to the private institutions to operate. As already described, many analysts attribute the cause of the crisis to the private companies and many others to the governmental response to this difficult situation. Therefore, another possible solution, which is being put into practice, consists of limiting the freedom of the private institutions to operate. Some analysts understand this limitation of freedom as an attack on the companies, which would only worsen the situation (The Wall Street Journal, 2013). Some claim that lowering taxes and giving freedom to the private institutions creates jobs and economic growth through the private initiative which would work much better than the governmental re-distribution (Taylor, 2013). On the other hand, others suggest that companies should be controlled more so that they pay adequate tax rates contributing to each country's economy. Those suggest that schools or hospitals are being closed while the big companies are getting richer (Tichon, 2013).

As already described, there are different opinions and no agreement on the causes and solutions to the current economic crisis. Politicians and economists are still discussing the issue, while the unemployment rates are extremely high in many countries and many people have no means to cover even their most basic needs. Authors of the current work strongly believe that science and education can contribute to the solution of this difficult situation. Science and education are crucial for the solution of the most important world problems (Deiaco, Hughes, \& McKelvey, 2012; OECD, 2012) and it is believed that they are crucial for the stimulation of the world economy (Avendaño, 2011). Therefore, the opinion of the most prestigious scientists and university teachers from all over the world on the causes and possible solutions to the crisis is crucial to improve the situation. For this reason, the objective of the current study consisted on collecting and analyzing the opinion of the world scientific community on the causes and possible solutions to the crisis, taking into account the community as a whole, and also comparing different geographic zones and fields of knowledge.

\section{Method and materials}

\section{Participants}

The survey was filled in by 1770 scientists from 87 different countries and all the fields of knowledge defined by UNESCO. Most of them were men (77.9\%) and $22.7 \%$ were women, with a mean age of 44.78 years $(\mathrm{SD}=12.46)$. The mean number of articles published by the respondents was of 67.96 $(\mathrm{SD}=92.78)$, and the research project of 18.83 $(\mathrm{SD}=29.44)$. The mean number of years of experience in teaching was of $13.21(\mathrm{SD}=12)$ and $18.93(\mathrm{SD}=11.88)$ in research. All participants were randomly selected from the Web of Science (Thomson Reuters).

\section{Instruments}

Authors of the current study designed a questionnaire, which consisted of 70 items divided in two parts, one related to the economical crisis in general and the other related to science and education. Results of the second part are published elsewhere. The first part of the questionnaire consisted of 15 items divided in two different sections with questions on what caused the economical crisis and what can be done to solve it. Items were answered utilizing a Likert scale ranging from 1 (Definitely in disagreement) to 5 (Definitely in agreement). The Cronbach's alphas were of 0.78 for the first scale and of 0.61 for the second scale.

\section{Design and procedure}

First, the authors of the study randomly selected articles from the Web of Science and then, email addresses were extracted from the information 


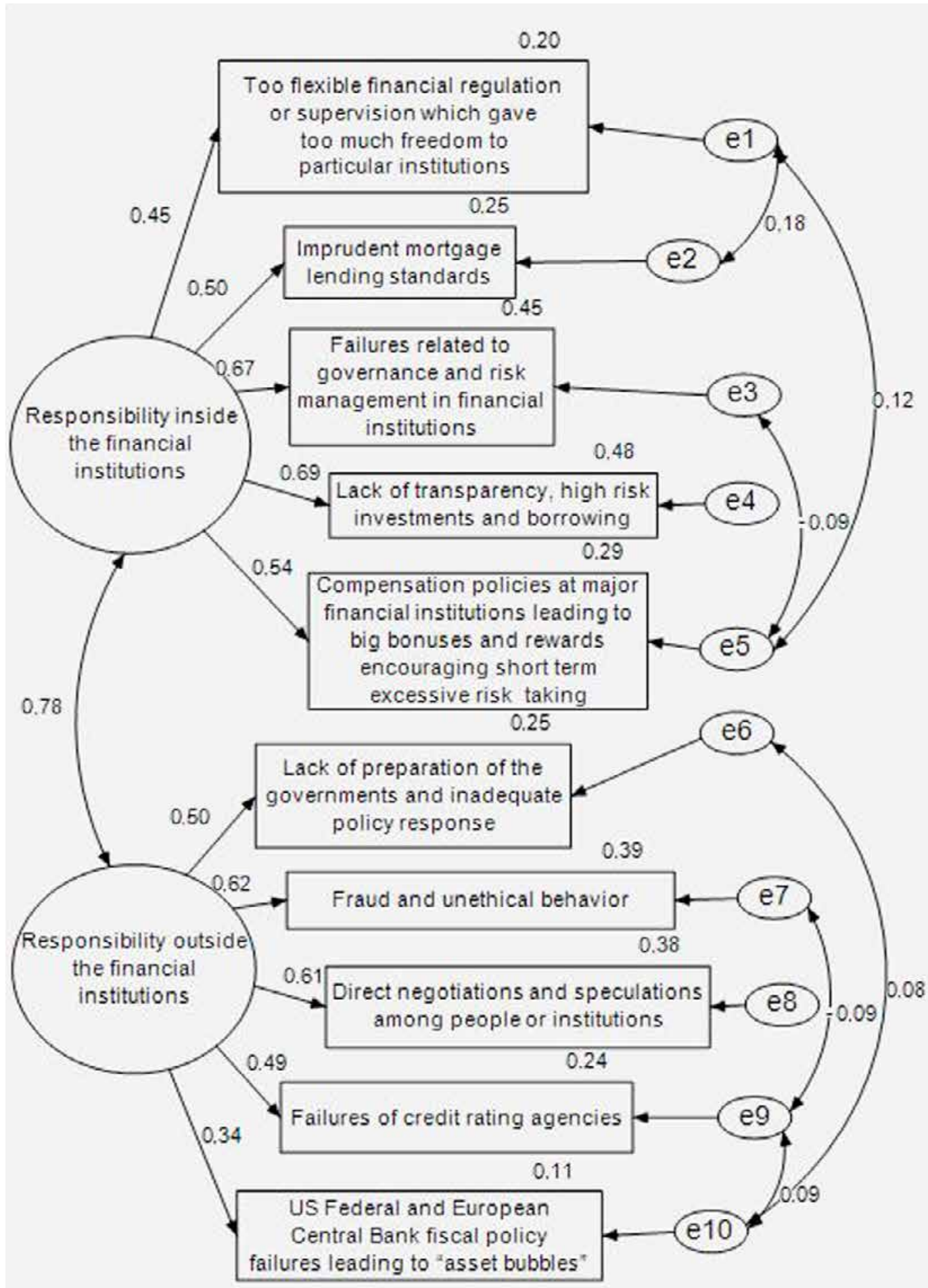

FIGURE 1. Confirmatory Factor Analysis of the scale on the opinion on the causes of the economic crisis.

Chi-square $=198.200 ; \mathrm{df}=28 ; p=0.0 ; \mathrm{CFI}=0.94 ; \mathrm{TLI}=0.91 ; \mathrm{NFI}=0.94 ; \mathrm{GFI}=0.98 ; \mathrm{AGFI}=0.95 ; \mathrm{RMR}=0.03 ; \mathrm{RM}$ $\mathrm{SEA}=0.06$.

Source: own work 
provided for correspondence in the papers. All participants received an email in which they were provided a link to a website with the questionnaire. Answers were automatically incorporated to a database and analyzed with SPSS 18 software. The study was completely anonymous and no personal data was collected. The number of exclusive visitors to the survey according to Google Analytics was of 4286. Therefore, the response rate can be estimated in $41.30 \%$.

\section{RESULTS}

The opinion on the causes

of the economic crisis

Kaiser-Meyer-Olkin test showed adequate structure for a factor analysis $(\mathrm{KMO}=0.849)$ and a principal component analysis with varimax rotation performed with SPSS showed the existence of two different factors. Confirmatory Factor Analysis with AMOS confirmed the two factors, which are shown in the Figure 1. The model shows good adjustment to the data and high factor loadings, ranging from 0.34 to 0.69 . The Cronbach's alpha for the whole scale was good $(\alpha=0.78)$ and acceptable for Factor $1(\alpha=0.71)$ and Factor $2(\alpha$ $=0.64$ ).

The analysis of items in each factor led the authors conclude that Subscale 1 groups the items related to the management and responsibility inside the financial institutions that originate the crisis. On the other hand, Subscale 2 groups items are related to the responsibility and management outside the financial institutions. Table 1 shows means and standard deviation in each item of the two subscales. Most answers are close to 4 , which means "somewhat in agreement". Taking into account the total scores, on both scales, they could range from 5 , which would mean "definitely in disagreement" to 25, which would mean "Definitely in agreement". As can be seen in table 1, respondents are in agreement in relation to the responsibility inside and also outside financial institutions.

Table 2 shows differences in the two subscales between the geographic zones. Levene test showed unequal variances and, therefore, Welch's ANOVA was used to find out whether the differences are statistically significant. Results show significant differences in both subscales. USA/

\section{TABLE 1.}

Means and Standard Deviations in each item and total scores in each subscale related to the opinion on the causes of the economic crisis.

\begin{tabular}{lc}
\hline & M (SD) \\
\hline SUBSCALE 1: RESPONSIBILITY INSIDE THE FINANTIAL INSTITUTIONS & $21.38(3.23)$ \\
Cronbach`s alpha = 0.71 & $4.16(1.1)$ \\
Too flexible financial regulation or supervision which gave too much freedom to particular institutions & $4.29(0.91)$ \\
Imprudent mortgage-lending standards & $4.42(0.82)$ \\
Failures related to governance and risk management in financial institutions & $4.40(0.87)$ \\
Lack of transparency, high risk investments and borrowing & $4.12(1)$ \\
Compensation policies at major financial institutions leading to big bonuses and rewards encouraging & $19.11(3.39)$ \\
short term excessive risk taking & $4.10(0.99)$ \\
SUBSCALE 2: RESPONSIBILITY OUTSIDE THE FINANTIAL INSTITUTIONS & $4.08(1.07)$ \\
Cronbach's alpha = 0.64 & $3.50(1.09)$ \\
Lack of preparation of the governments and inadequate policy response & $3.65(1.13)$ \\
Fraud and unethical behavior & $3.78(1.02)$ \\
Direct negotiations and speculations among people or institutions & \\
Failures of credit rating agencies & \\
US Federal and European Central Bank fiscal policy failures leading to "asset bubbles"
\end{tabular}

ANOVA among the items: $F_{(9)}=217.641, p=0.0$

Source: own work 
Canada $(\mathrm{M}=22.33, \mathrm{SD}=2.84)$ and Australia $(\mathrm{M}=22.37, \mathrm{SD}=2.51)$ are the zones with the highest scores in the Subscale 1 and Asia is the one with the lowest score $(\mathrm{M}=19.35, \mathrm{SD}=$ 3.91). On the other hand, Latin America ( $M=$ 19.30, SD = 3.7) USA/Canada $(\mathrm{M}=19.29$, SD $=3.25)$ and Europe $(\mathrm{M}=19.27, \mathrm{SD}=3.32)$ are the zones with the highest scores in the Subscale 2, whereas Asia is the zone with the lowest score $(\mathrm{M}=18.21, \mathrm{SD}=3.76)$.

Games Howell post hoc comparisons showed significant differences in the Subscale 1 between Africa and Asia (Mean difference $=1.68, p=$ $0.044, d=0.5$ ), Australia and Asia (Mean difference $=3.02, p=0.0, d=0.92)$, Australia and Latin America (Mean difference $=1.75, p=$ 0.039, $d=0.6$ ), USA/Canada and Asia (Mean difference $=2.98, p=0.0, d=0.87$ ), Europe and Asia (Mean difference $=2.11, p=0.0, d=$ 0.61), USA/Canada and Europe (Mean difference $=0.87, p=0.0, d=0.3)$ and USA/Canada and Latin America (Mean difference $=1.71, p=$ 0.007, $d=0.56$ ).

Significant differences in Subscale 2 were found between USA/Canada and Asia (Mean difference $=1.08, p=0.006, d=0.31)$ and Europe and Asia (Mean difference $=1.06, p=$ $0.003, d=0.3)$. No significant differences in the subscales were found among different fields of knowledge. Welch's ANOVA was non-significant in the Subscale $1\left(F_{(5)}=1.852, p=0.101\right)$ and in the Subscale $2\left(F_{(5)}=0.770, p=0.572\right)$.

\section{Opinion on the solutions to the economic crisis}

At the beginning, this part of the questionnaire consisted of 9 items but the analysis of the correlations item-total and the item analysis based on the comparison of the means of the groups with the highest and the lowest scores (items with non-significant $t$ test values are eliminated) led to the elimination of 4 items (Morales, 2011). Therefore, the final scale consisted of 5 items with an acceptable Cronbach's alpha $(\alpha=0.61)$. An Exploratory Factor Analysis with SPSS showed the existence of only one factor with loadings between 0.48 and 0.69. Kaiser-Meyer-Olkin test showed adequate structure for a factor analysis $(\mathrm{KMO}=$ 0.69) and for the final model were reversed items "Increasing taxation" and "Promote mostly public employment". A Confirmatory Factor Analysis with AMOS confirmed this one factor structure with very good fit and loadings between 0.27 and 0.56 (Figure 2).

Table 3 shows means and standard deviations on each item of the scale. It also shows the total score calculated inverting the items "Increasing taxation" and "Promote mostly public employment" taking into account the theoretical basis of the scale described in the introduction. The total score on the scale range from range from 5 , which would mean "definitely in agreement with the public solution to the crisis" to 25, which would mean "Definitely in agreement with the private solution to the crisis".

TABLE 2.

Differences in total scores in the two subscales among the geographic zones.

\begin{tabular}{|c|c|c|c|c|c|c|c|}
\hline & $\begin{array}{c}\text { AFRICA } \\
(30) \\
M(S D) \\
\end{array}$ & $\begin{array}{c}\text { AUSTRALIA } \\
(46) \\
M(\mathrm{SD}) \\
\end{array}$ & $\begin{array}{c}\text { ASIA } \\
(213) \\
M(S D) \\
\end{array}$ & $\begin{array}{c}\text { USA/ } \\
\text { CANADA } \\
\text { (395) M (SD) } \\
\end{array}$ & $\begin{array}{c}\text { EUROPE } \\
(913) \\
M(S D) \\
\end{array}$ & $\begin{array}{c}\text { LATIN } \\
\text { AMERICA } \\
\text { (73) M (SD) } \\
\end{array}$ & $\mathrm{F}_{(5)}$ \\
\hline $\begin{array}{l}\text { SUBSCALE 1: Respon- } \\
\text { sibility inside the finan- } \\
\text { cial institutions } \\
\alpha=.71\end{array}$ & $\begin{array}{l}21.03 \\
(2.67)\end{array}$ & $\begin{array}{l}22.37 \\
(2.51)\end{array}$ & $\begin{array}{l}19.35 \\
(3.91)\end{array}$ & $\begin{array}{l}22.33 \\
(2.84)\end{array}$ & $\begin{array}{l}21.46 \\
(2.98)\end{array}$ & $\begin{array}{l}20.62 \\
(3.23)\end{array}$ & a $21.247 * *$ \\
\hline $\begin{array}{l}\text { SUBSCALE 2: Respon- } \\
\text { sibility outside the finan- } \\
\text { cial institutions } \\
\alpha=.64\end{array}$ & $\begin{array}{l}19.03 \\
(2.99)\end{array}$ & $\begin{array}{c}18.5 \\
(3.23)\end{array}$ & $\begin{array}{l}18.21 \\
(3.76)\end{array}$ & $\begin{array}{l}19.29 \\
(3.25)\end{array}$ & $\begin{array}{l}19.27 \\
(3.32)\end{array}$ & $\begin{array}{l}19.3 \\
(3.7)\end{array}$ & a3.388** \\
\hline
\end{tabular}




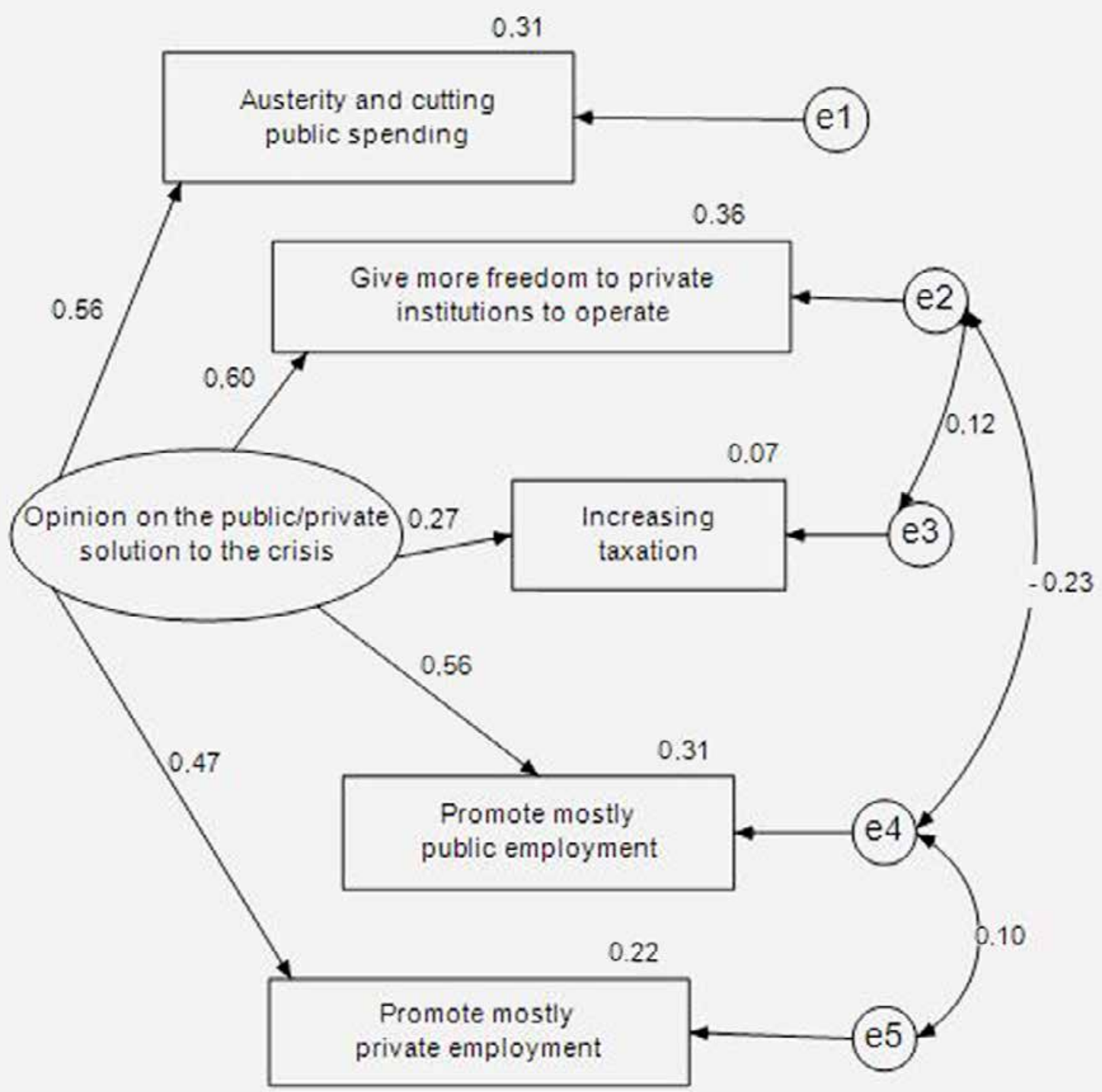

Figure 2. Confirmatory Factor Analysis of the scale on the opinion on the public/private solution to the economic crisis.

Chi-square $=3.296 ; \mathrm{df}=2 ; p=0.192 ; \mathrm{CFI}=1.0 ; \mathrm{TLI}=0.99 ; \mathrm{NFI}=1.0 ; \mathrm{GFI}=1.0 ; \mathrm{AGFI}=0.99 ; \mathrm{RMR}=0.01 ; \mathrm{RMSEA}=0.02^{*}$ Source: own work

* The scores of the items "increasing taxation" and "promote mostly public employment" were inverted taking into account their theoretical basis.

The mean in this scale shows that respondents are just in between these two possibilities $(\mathrm{M}=14.99$, $\mathrm{SD}=3.88)$.

Table 4 shows differences in the total score on the scale on the opinion on the public/private solution to the crisis among different geographic zones. There were significant differences among zones and Games Howell post hoc comparisons showed significant differences between Africa and USA/ Canada (Mean difference $=2.13, p=0.007, d=$ 0.59), Asia and USA/Canada (Mean difference $=$ 2.16, $p=0.0, d=0.59$ ), Asia and Europe (Mean difference $=0.81, p=0.014, d=0.23$ ), Europe and USA/Canada (Mean difference $=1.35, p=0.0$, $d=0.34$ ) and Latin America and USA/Canada (Mean difference $=2.33, p=0.0, d=0.6$ ). There- 
TABLE 3.

Means and Standard Deviations in each item and total scores in the scale the opinion on the public/private solution to the economic crisis.

\begin{tabular}{lc}
\hline & M (SD) \\
\hline SCALE: OPINION ON THE PUBLIC/PRIVATE SOLUTION TO THE ECONOMIC CRISIS & $14.99(3.88)$ \\
Austerity and cutting public spending & $2.86(1,41)$ \\
Give more freedom to private institutions to operate & $2.16(1.23)$ \\
Increasing taxation & $2.82(1.31)$ \\
Promote mostly public employment & $2.74(1.18)$ \\
Promote mostly private employment & $3.54(1.07)$ \\
\hline
\end{tabular}

ANOVA among the items: $F_{(4)}=251.093, p=.000^{* *}$

Source: own work

** The scores of the items "increasing taxation" and "promote mostly public employment" were inverted for the calculation of the total score taking into account their theoretical basis.

TABLE 4.

Differences in total scores on the scale on the opinion on the public/private solution to the economic crisis among the geographic zones.

\begin{tabular}{|c|c|c|c|c|c|c|c|}
\hline & $\begin{array}{c}\text { AFRICA } \\
(30) \\
M(\text { SD) }\end{array}$ & $\begin{array}{c}\text { AUSTRALIA } \\
(46) \\
M(\mathrm{SD})\end{array}$ & $\begin{array}{c}\text { ASIA } \\
\text { (213) } \\
\text { M (SD) }\end{array}$ & $\begin{array}{c}\text { USA/ } \\
\text { CANADA } \\
\text { (395) } \\
\text { M (SD) } \\
\end{array}$ & $\begin{array}{c}\text { EUROPE } \\
\text { (913) } \\
\text { M (SD) }\end{array}$ & $\begin{array}{c}\text { LATIN } \\
\text { AMERICA } \\
(73) \\
\text { M (SD) } \\
\end{array}$ & $F_{(5)}$ \\
\hline $\begin{array}{l}\text { SCALE: Opinion on the } \\
\text { public/private solution to the } \\
\text { economic crisis } \\
\alpha=0.61\end{array}$ & $\begin{array}{l}15.93 \\
(2.9)\end{array}$ & $\begin{array}{l}14.83 \\
(3.69)\end{array}$ & $\begin{array}{l}15.97 \\
(3.07)\end{array}$ & $\begin{array}{l}13.81 \\
(4.14)\end{array}$ & $\begin{array}{l}15.16 \\
(3.89)\end{array}$ & $\begin{array}{l}16.14 \\
(3.66)\end{array}$ & ${ }^{\mathrm{a}} 12.65 * *$ \\
\hline
\end{tabular}

fore, scientists from USA/Canada were the least in agreement and the scientists from Latin America were the most in agreement with the private solution to the crisis. ANOVA analysis showed no significant differences among the fields of knowledge $\left(F_{(5)}=2.034, p=0.072\right)$.

As results showed that respondents were neither in agreement nor in agreement with public/ private solution to the crisis, a cluster analysis was performed to identify whether there are different profiles of respondents. Two-step cluster analysis with the five items of the scale showed three different clusters with fair quality according to the Silhouette measure of cohesion and separation. All items were used for clustering, although the items "Austerity and cutting public spending" and "Give more freedom to private institutions to operate" were more important than the rest. The clusters can be seen in table 5 .

Cluster 1 with $50 \%$ of participants is in agreement with austerity and cutting public spending, in disagreement with giving more freedom to private institutions and in agreement with promoting mostly private employment. Cluster 2 with $15.2 \%$ of participants shows similar tendency, although much more extreme than Cluster 1 (more moderate), also being in agreement with giving more freedom to private institutions to operate, and in disagreement with increasing taxation or promoting mostly public employment. Cluster 3 with $34.8 \%$ of participants is just the opposite of Cluster 2, in disagreement with austerity and cutting public spending or giving more freedom to private institutions. Table 6 shows percentages of participants from each geographic zone in each cluster. Asia is the 
TABLE 5.

Cluster analysis of the respondents to the items of the on the opinion on the public/private solution to the economic crisis

\begin{tabular}{|c|c|c|c|}
\hline & $\begin{array}{c}\text { Cluster } 1 \\
50 \% \\
\text { Mean } \\
\end{array}$ & $\begin{array}{c}\text { Cluster } 2 \\
15.2 \% \\
\text { Mean } \\
\end{array}$ & $\begin{array}{c}\text { Cluster } 3 \\
34.8 \% \\
\text { Mean } \\
\end{array}$ \\
\hline $\begin{array}{l}\text { Austerity and cutting public spending } \\
\text { (Importance = 1) }\end{array}$ & 3.5 & 4.03 & 1.42 \\
\hline $\begin{array}{l}\text { Give more freedom to private institutions to operate } \\
\text { (Importance }=0.68 \text { ) }\end{array}$ & 2.17 & 3.89 & 1.38 \\
\hline $\begin{array}{l}\text { Increasing taxation } \\
(\text { Importance }=0.22)\end{array}$ & 2.87 & 1.64 & 3.28 \\
\hline $\begin{array}{l}\text { Promote mostly public employment } \\
\text { (Importance }=0.33 \text { ) }\end{array}$ & 2.65 & 1.58 & 3.36 \\
\hline $\begin{array}{l}\text { Promote mostly private employment } \\
\text { (Importance }=0.27 \text { ) }\end{array}$ & 3.59 & 4.52 & 3.04 \\
\hline
\end{tabular}

Source: own work

TABLE 6.

Percentages of participants from different geographic zones in each cluster.

\begin{tabular}{lccc}
\hline & Cluster 1 & Cluster 2 & Cluster 3 \\
\hline AFRICA & $60 \%$ & $16.7 \%$ & $23.3 \%$ \\
AUSTRALIA & $47.8 \%$ & $13 \%$ & $39.1 \%$ \\
ASIA & $65.3 \%$ & $19.7 \%$ & $14.1 \%$ \\
USA/CANADA & $39.7 \%$ & $10.9 \%$ & $49.4 \%$ \\
EUROPE & $49.8 \%$ & $15.9 \%$ & $34.1 \%$ \\
LATIN AMERICA & $54.8 \%$ & $17.8 \%$ & $27.4 \%$ \\
TOTAL & $50 \%$ & $15.2 \%$ & $34.8 \%$ \\
\hline
\end{tabular}

Chi-square $=86.47 ; \mathrm{df}=15 ; p=0.0$

Source: own work

geographic zone with the highest percentage and USA/Canada has the lowest percentage in Clusters 1 and 2. On the other hand, USA/Canada is the zone with the highest percentage and Asia is the zone with the lowest percentage in the Cluster 3 .

\section{Discussion}

The economic crisis started in 2007-2008 (Claessens, Dell'Ariccia, Igan, \& Laeven, 2010; United States. Financial Crisis Inquiry Commission, 2011) and since then, governments put into practice policies to palliate its effect. Cuttings and austerity now is affecting the quality of crucial sectors such as science, education or healthcare system (Baker, Bloom, \& Davis, 2013) also having negative effects on the psychological well being of the population
(Anagnostopoulos \& Sumaki, 2013; Christodoulou \& Anagnostopoulos, 2013; Gili, Roca, Basu, Mckee, \& Stuckler, 2012).

Taking into account this difficult situation and the impact of the crisis on the population, the objective of this study consisted on describing the opinion of the world scientific community about the causes and possible solutions to the crisis, comparing different geographic zones and fields of knowledge. The opinion of the scientific community worldwide is considered crucial, as it is an engine to the progress of individuals and societies. Science is a hope to solve many important world problems, such as hunger or global warming (Deiaco, Hughes, \& McKelvey, 2012; OECD, 2012) and also the economic downturns (Avendaño, 2011). On the other hand, results 
show that participants are in agreement that the crisis was originated inside and also outside financial institutions, this finding seems to be in line with the previous studies (Rose \& Spiegel, 2012).

These causes are now observed in the world economic panorama (Kirman, 2010). As already described by Moreno (2010) the causes can be grouped into two main blocks: one related to the management and policy inside the financial institutions and the other outside referring to policies and management conducted, for example, by governments. These results are in agreement with what was described in the introduction (Acharya \& Richardson, 2009; Archarya \& Schnabl, 2010; Crotty, 2009; Vasco \& Porporatto, 2011). Taking into account the specific causes, the most important issues inside the financial institutions, according to respondents are related to failures in governance, risk management and lack of transparency, high-risk investments and borrowing. On the other hand, issues such as lack of preparation of the governments and inadequate policy response, as well as fraud and unethical behavior were the most important causes of the crisis outside financial institutions, which is related to what was described by some analysts (Adams, 2012; Beltratti \& Stulz, 2012; Wallison, 2009).

There were no differences among the fields of knowledge and taking into account the geographic zones, USA/Canada and Australia are the zones with the highest scores and Asia is the zone with the lowest score with respect to the responsibility inside the financial institutions. On the other hand, Latin America, USA/Canada and Europe are the zones with the highest scores, whereas Asia is the zone with the lowest score related to the responsibility outside the financial institutions. These differences might be related to differences in the impact of the crisis on each geographic zone. As already described, the crisis started in the USA, affects a lot of European countries and its impact is much smaller in Asia (Aalbers, 2009; Song \& Lin, 2010).

Taking into account the solutions, participants seem indecisive and are neither in agreement nor in disagreement with public/private solutions to the crisis. It seems that in most cases, they suggest something in between these two extremes, trying to find solutions from the governments and also from private companies and people. Taking into account the geographic zones, scientists from USA/Canada were the least in agreement and scientists from Latin America were the most in agreement with the private solution to the crisis.

The analysis of the different profiles of participants shows that $50 \%$ of participants are in agreement with austerity and cutting public spending, in disagreement with giving more freedom to private institutions, and in agreement with promoting mostly private employment. These participants can be considered more moderate, in agreement with the private initiative but controlling at the same time the companies. Another profile, more extreme, with $15.2 \%$ is in agreement with the private solution and in disagreement with public solutions to the crisis. Finally, the third profile with $34.8 \%$ is the one mostly in agreement with the public solution to the current situation. Taking into account the geographic zones, Asia is the continent with the smallest percentage in the third profile and the highest percentage in the first and the second profiles, probably because it is less affected by the crisis in comparison to the rest, and also because the scientists from this zone promote private initiative. On the other hand, USA/Canada has the highest percentage in the third profile, probably because of the strong development of the private initiative, which is already present, feeling now the necessity of the governmental action that would solve the problem.

As already described, results of the current study show that, according to the scientists, the crisis is a multicausal phenomenon, in line with the previous studies (Nadal, 2008). In relation to the solutions, the highest percentage of participants is in agreement with a policy that promote private initiative but at the same time, with a public support and some control. These results are very interesting when analyzing the crisis and, 
above all, they should be taken into account while managing this difficult situation.

\section{References}

Aalbers, M. (2009). Geographies of the financial crisis. Area, 41(1), 34-42.

Acharya, V. V., \& Richardson, M. (2009). Causes of the financial crisis. Critical Review, 21(2-3), 195-210.

Acharya, V. V., \& Schnabl, P. (2010). Do Global Banks Spread Global Imbalances \& quest; Asset-Backed Commercial Paper during the Financial Crisis of 2007-09. IMF Economic Review, 58(1), 37-73.

Adams, R. (2012), 'Governance and the Financial Crisis'. International Review of Finance, 12, 7-38

Allen, F., \& Carletti, E. (2010). An Overview of the Crisis: Causes, Consequences, and Solutions*. International Review of Finance, 10(1), 1-26.

Anagnostopoulos, D. C., \& Sumaki, E. (2013). The state of child and adolescent psychiatry in Greece during the international financial crisis: a brief report. European Child EO Adolescent Psychiatry, 22(2), 131-134.

Arghyrou, M. G., \& Tsoukalas, J. D. (2011). The Greek debt crisis: Likely causes, mechanics and outcomes. The World Economy, 34(2), 173-191.

Atoyan, R., Manning, J., \& Rahman, J. (2013). Rebalancing: Evidence from Current Account Adjustment in Europe. IMF Working Paper. International Monetary Fund. Retrieved from http://www.imf. org/external/pubs/cat/longres.aspx?sk $=40422.0$ Accessed June 15, 2013.

Avendaño López, M. D. C. (2011). La ciencia en España. Reflexiones sobre la Ley de la Ciencia, la Tecnología y la Innovación [Science in Spain. Reflections on the Law of Science, Technology and Innovation]. Anales de la Real Academia Nacional de Farmacia, 77(2), 1-9.

Baker, S., Bloom, N., \& Davis, S. (2013). Measuring economic policy uncertainty. Chicago booth Research Paper, 13-02.

Beltratti, A., \& Stulz, R. M. (2012). The credit crisis around the globe: Why did some banks perform better?. Journal of Financial Economics, 105(1), 1-17.
Bibow, J. (2013). At the crossroads: The euro and its central bank guardian (and saviour?). Cambridge Journal of Economics, 37(3), 609-626.

Brondolo, J. (2009). Collecting Taxes During an Economic Crisis: Challenges and Policy Options. IMF Staff Position Note. Retrieved from http://www.imf.org/ external/pubs/ft/spn/2009/spn0917.pdf. Accessed June 15, 2013.

Carballo, F. (2011). Causes and consequences of the Spanish economic crisis: Why the recovery is taken so long? Panoeconomicus, 58(3), 309-328.

Christodoulou, N.G., \& Anagnostopoulos, D.C. (2013). The financial crisis and the future of mental health in Greece. International Psychiatry, 10(1), 3-5.

Crotty, J. (2009). Structural causes of the global financial crisis: a critical assessment of the "new financial architecture". Cambridge Journal of Economics, 33(4), 563-580.

Crotty, J. (2012). The great austerity war: what caused the US deficit crisis and who should pay to fix it? Cambridge Journal of Economics, 36(1), 79-104.

Dolls, M., Fuest, C., \& Peichl, A. (2010). Automatic stabilizers and economic crisis: US vs. Europe (No. w16275). National Bureau of Economic Research.

Espinosa, J. C. (2013). La crisis financiera: iestafa, mala gestión empresarial, mal manejo macroeconómico o una falta de regulaciones? de nuevo las enseñanzas [The financial crisis: scam, bad management, macroeconomic mismanagement or lack of regulations? teaching again]. Economía y sociedad, 37-38, 23-54.

García de Fuentes, A., and Morales, J. (2013). Crisis y procesos territoriales [Crisis and territorial processes]. Problemas del Desarrollo, 21(82).

Gili, M., Roca, M., Basu, S., McKee, M., \& Stuckler, D. (2012). The mental health risks of economic crisis in Spain: evidence from primary care centres, 2006 and 2010. European Journal Public Health. http:// dx.doi.org/10.1093/eurpub/cks035.

IMF (2009). Regional Economic Outlook. Sub-Saharan Africa.

Kilian, L., \& Hicks, B. (2012). Did unexpectedly strong economic growth cause the oil price shock of 2003-2008?. Journal of Forecasting. Retrieved from http://onlinelibrary.wiley.com/doi/10.1002/ 
for.2243/abstract?deniedAccessCustomisedMessa ge $=$ \&userIsAuthenticated $=$ false.

Kirman, A. (2010). The economic crisis is a crisis for economic theory. CESifo Economic Studies, 56(4), 498-535.

Lichtensztejn, S. (2013). Efectos sociales y políticos de la actual crisis financiera internacional [Social and political effects of the current international financial crisis]. Ola Financiera, 5(11), 50-64.

Martin, R. (2011). The local geographies of the financial crisis: from the housing bubble to economic recession and beyond. Journal of Economic Geography, 11(4), 587-618.

Nadal, A. (2008). La crisis financiera de Estados Unidos [The finantial crisis in E.E.U.U.]. Boletín Económico de ICE, Información Comercial Española, (2953), 19-29.

OECD (2006). Promoting Private Investment for Development. The role of ODA. Retrieved from www. oecd.org/dataoecd/23/40/36566902.pdf.

OIT (2013). Global Employment Trends 2013: Recovering from a second jobs dip. Global Employment Trends: Organización Internacional del Trabajo.

Posner, R. (2009). A failure of Capitalism. United States. Harvard University Press.

Reinhart C., \& Rogoff K. The aftermath of financial crises. NBERWorking Paper No. 146562009.

Rose, A. K., \& Spiegel, M. M. (2012). Cross-country causes and consequences of the 2008 crisis: early warning. Japan and the World Economy, 24(1), 1-16.

Taylor, J.C. (2013). Letter. The Wall Street Journal, Retrieved from http://online.wsj.com/article/SB10
001424127887323610704578629700556046428. html?KEYWORDS=taxation.

Terazi, E., \& Şenel, S. (2011). The Effects of the Global Financial Crisis on the Central and Eastern European Union Countries. International Journal of Business and Social Science, 2(17), 186-192.

Tichon, N. (2013). Letter. The Wall Street Journal, Retreived from http://online.wsj.com/article/SB10 001424127887323610704578629700556046428. html?KEYWORDS=taxation.

The Wall Street Journal (2013). A global revenue grab. Retrieved from: http:/online.wsj.com/article/SB 10001424127887324783204578619513367745012. html\#articleTabs\%3Darticle.

United States. Financial Crisis Inquiry Commission. (2011). Financial crisis inquiry report: final report of the national commission on the causes of the financial and economic crisis in the United States. Government Printing Office.

Vasco, D. C., \& Porporatto, P. (2011). Aspectos tributarios de las Operaciones Financieras, con Énfasis en los Instrumentos y/o Contratos Derivados [Tax aspects of Financial Operations, with emphasis on the instruments and / or derivatives contracts]. Administración Tributaria, 31, 34.

Wahrig, L., \& Gancedo Vallina, I. (2011). The effect of the economic and financial crisis on government revenue and expenditure. Retrieved from http:// epp.eurostat.ec.europa.eu/cache/ITY_OFFPUB/ KS-SF-11-045/EN/KS-SF-11-045-EN.PDF.

Zai, P. (2012). The economic crisis and fiscal trends in EU member states. Transylvanian Review of Administrative Sciences, 35, 256-268. 
